\title{
Time for an Italian renaissance?
}

\author{
Italy's national science \\ academy is celebrating \\ its 400th anniversary, in \\ part by cataloguing its \\ wealth of intellectual \\ treasures. But can it \\ reinvent itself as a \\ modern, politically \\ relevant body? \\ Alison Abbott reports.
}
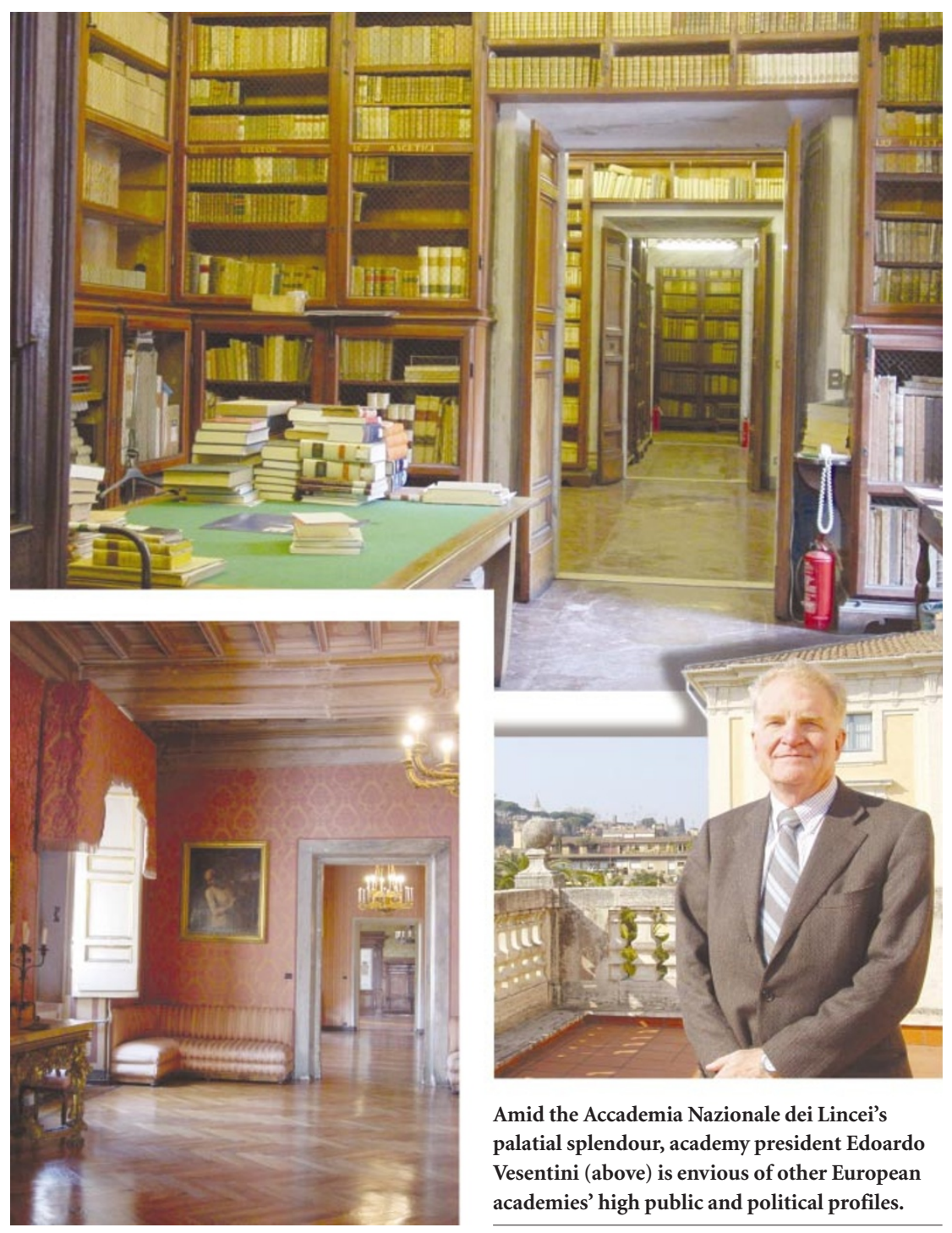

Amid the Accademia Nazionale dei Lincei's palatial splendour, academy president Edoardo Vesentini (above) is envious of other European academies' high public and political profiles.

was founded in 1603 as the Accademia dei Lincei - literally, the 'academy of the lynxes' - by the nobleman Federico Cesi, then just 18 years old. Cesi was an idealist who wanted to understand the world through observation which is why he named his creation after a creature that was then thought to have particularly acute vision. That philosophy also explains the hostility encountered by the nascent academy, which immediately began to challenge received classical and biblical wisdom. Cesi was disowned by his father; other members most famously Galileo Galilei, who became the sixth Lincean in 1611 - were denounced by the Roman Catholic Church. "The academy was born fighting," says Vesentini.

Financial and moral support for the original Lincei died with Cesi in 1630. The academy resurfaced several times, but received strong backing only in 1847 — ironically, given its
Britain and France, which regularly provide scientific advice to their governments.

The academy's history is a colourful one. It da Vinci. Already, some of the jewels in the academy's collection of historic scientific 


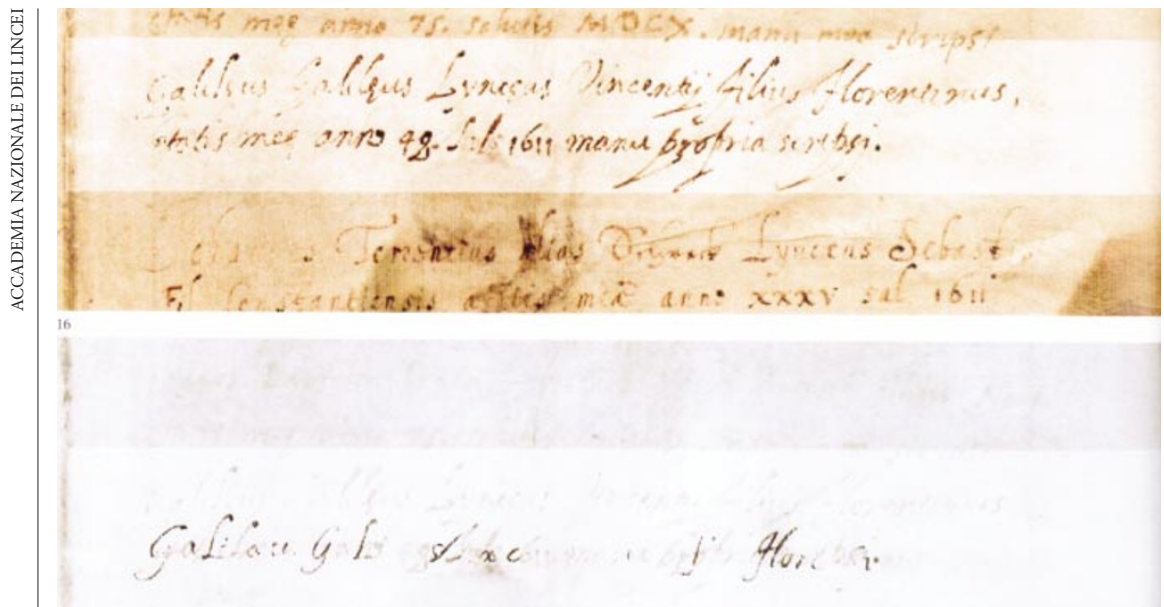

Hand of history: as part of the Lincei's quadricentennial celebrations, scientists have digitally restored the academy's original charter, featuring Galileo's signature (top, restored; bottom, before restoration).

rebellious past, from the ultra-conservative Pope Pius IX, who named the organization the Pontifical Academy of the New Lincei. With the unification of Italy in 1870 , however, most Linceans swore allegiance to the new nation and its king, breaking away to form what was eventually to become the Accademia Nazionale deiLincei of today.

By this time, many of the manuscripts and drawings of Cesi's original academy had been sold, but new collections were being assembled. And in 1883, the Italian state installed the academy in the Corsini Palace — still its home today - complete with its valuable library, on the condition that this remained open to the public.

\section{Mergers and purges}

Over the ensuing four decades, the academy enjoyed relative calm - until the advent of fascism. In 1926, Benito Mussoliniestablished the rival Accademia d'Italia, which he housed in the Villa Farnesina, a gem of Renaissance architecture across the road from the Corsini Palace. Put under political pressure, all but eight of the 150 Linceans declared their allegiance to the fascist regime in the 1930s, and the two academies were merged in 1939. After the fall of Mussolini in 1944, however, the Lincei was re-established in its traditional form, and its membership purged of fascist appointments. It moved back into the Corsini Palace, but also inherited the Villa Farnesina, complete with treasures including a room decorated with frescoes by Rafael.

It is the academy's cultural heritage that is being emphasized in the quadricentennial celebrations. Three years ago, when Manzari and her colleagues began to catalogue the Lincei's library in preparation to exhibit its manuscripts, they faced a mammoth task. "Many manuscripts were described with only one or two handwritten sentences," says Manzari. "We found lots of surprises, lots of treasures."

These neglected riches include sacred manuscripts, plus records of major engineer- ing and architectural works - such as accounts of payments to two of the most important baroque architects, Francesco Borromini and Giovanni Lorenzo Bernini, for projects commissioned by Pope Innocent X. "I didn't know about this resource," enthuses Jürgen Renn, a director at the Max Planck Institute for the History of Science in Berlin, who is coordinating a European project to publish documents on the Internet that reveal the evolution of mechanical knowledge.

The exhibited works also include eight volumes of coloured drawings commissioned by Cesi, who wanted to create a complete visual record of natural history. The 1,365 pages reveal the illustrators' scientific approach. Plants, for example, are shown at all stages of their development, and include details observed for the first time under the microscope - a term coined by the Linceans.

This exquisite collection - "an infinitesimal part of all the material we have", according to Vesentini - has now been digitized, and Vesentini hopes that they will be made available on the Internet. In addition, the Linceans' original charter, dating from 1611 , has been digitally restored by scientists from the University of Bologna and Fotoscientifica, a digital-imaging company in Parma. On the document, the previously indistinct signature of Galileo now stands out boldly. Vesentini's dream is to annotate and digitize the library's entire contents, but its relatively meagre income in government grants means that this remains a distant goal.

"The government is not supportive," laments Vesentini, who looks enviously at Britain's Royal Society and the French Academy of Sciences - founded on Lincean principles in 1660 and 1666 , respectively. Not only are these academies financed more generously, he says, but they also have a higher public profile. "Ordinary people are aware that these academies have authority," Vesentini says.

In truth, Vesentini probably overestimates the familiarity of the average British or
French citizen with their respective national science academies. But the Lincei's most obvious counterparts certainly have more political clout. "It's not clear why the Accademia dei Lincei is not a prominent player in science policy," says Royal Society president Robert May. "It's certainly not for lack of superb scientists in Italy."

The Lincei is, officially, supposed to provide scientific advice to the Italian President, but is infrequently consulted and never volunteers its opinion. In any case, the Italian presidency is a largely ceremonial office, and the academy has no meaningful relationship with Italy's real custodians of power. Successive administrations have chosen not to seek its views - even on issues such the constant reforms that have shaken up the Italian research system over the past decade.

Some of the more active Linceans are trying to boost the academy's profile, for instance by organizing conferences for the public. "And we have started to go out into schools in different cities to give talks," says academy member Lamberto Maffei, director of the Institute of Neuroscience in Pisa, a part of the CNR, Italy's national research council.

\section{Age-old problem}

But attempts to enliven the academy have not been helped by a policy that, until recently, allowed new members to be appointed only when an existing Lincean died. Of the academy's 150 full members, 17 are in their nineties and 44 are octogenarians. Just 36 are under the age of 70. Since 2000, two or three of the oldest have been moved each year into a new category of membership, allowing replacements to be appointed from the ranks of corresponding members. This has reduced the Linceans' average age, but only from 78 to 76 .

Perhaps the biggest obstacle, however, is the academy's entrenched suspicion of governments - perhaps a legacy of its turbulent history - and a curious ambivalence towards the value of assuming a higher public profile. "If people know about us but get the wrong idea about us, it could harm us," muses Vesentini. In January, for instance, one of the academy's standing committees produced a paper endorsing the continued development of genetically modified crops. Tellingly, however, this was published as a statement by the committee, rather than by the academy as a whole.

Some of the academy's new, younger members argue that it's time for these attitudes to change - although they're not optimistic. "The Accademia doesn't push hard enough to get things done," says Jacopo Meldolesi, a molecular neuroscientist at the San Raffaele Scientific Institute in Milan, who was elected to the Lincei's ranks last year. "The membership is too old."

Alison Abbott is Nature's senior European correspondent. www.lincei.it/english.version/ default.english.html 